\title{
Regulation of chloride transport in cultured normal and cystic fibrosis keratinocytes
}

\author{
M. Kansen a , J. Keulemans ${ }^{\text {a }}$, A.T. Hoogeveen ${ }^{\text {a }}$, B. Scholte ${ }^{\text {a }}$, A.B. Vaandrager ${ }^{\text {b }}$, \\ A.W.M. van der Kamp ${ }^{a}$, M. Sinaasappel ${ }^{c}$, A.G.M. Bot ${ }^{b}$, H.R. de Jonge ${ }^{b}$ \\ and J. Bijman ${ }^{\text {a }}$ \\ a Department of Cell Biology I and Genetics, Erasmus University, Rotterdam (Netherlands), ' Department of Biochemistry I, \\ Erasmus University, Rotterdam (Netherlands) and ' Department of Gastroenterology, Erasmus University, Rotterdam (Netherlands)
}

(Received 21 October 1991)

Key words: Chloride channel; Chloride transport; Cystic fibrosis; Keratinocyte; Cell culture

Cultured normal $(\mathrm{N})$ and cystic fibrosis $(\mathrm{CF})$ keratinocytes were evaluated for their $\mathrm{Cl}^{-}$-transport properties by patch-clamp-, Ussing chamber- and isotopic efflux-measurements. Special attention was paid to a $32 \mathrm{pS}$ outwardly rectifying $\mathrm{Cl}^{-}$channel which has been reported to be activated upon activation of cAMP-dependent pathways in N, but not in CF cells. This depolarization-induced $\mathrm{Cl}^{-}$channel was found with a similar incidence in $\mathrm{N}$ and $\mathrm{CF}$ apical keratininocyte membranes. However, activation of this channel in excised patches by protein kinase (PK)-A or PK-C was not successfull in either N or CF keratinocytes. Forskolin was not able to activate $\mathrm{Cl}^{-}$channels in $\mathrm{N}$ and $\mathrm{CF}$ cell-attached patches. The $\mathrm{Ca}^{2+}$-ionophore A23187 activated in cell-attached patches a linear $17 \mathrm{pS} \mathrm{Cl}^{-}$channel in both $\mathrm{N}$ and $\mathrm{CF}$ cells. This channel inactivated upon excision. No relationship between the cell-attached $17 \mathrm{pS}$ and the excised $32 \mathrm{pS}$ channel could be demonstrated. Returning to the measurement of $\mathrm{Cl}^{-}$transport at the macroscopic level, we found that a drastic rise in intracellular cAMP induced by forskolin did in $\mathrm{N}$ as well as CF cells not result in a change in the short-circuit current $\left(I_{\mathrm{sc}}\right)$ or the fractional efflux rates of ${ }^{36} \mathrm{Cl}^{-}$and ${ }^{125} \mathrm{I}^{-}$. In contrast, addition of $\mathrm{A} 23187$ resulted in an increase of the $I_{\mathrm{sc}}$ and in the isotopic anion efflux rates in $\mathrm{N}$ and $\mathrm{CF}$ cells. We conclude that $\mathrm{Cl}^{-}$-transport in cultured human keratinocytes can be activated by $\mathrm{Ca}^{2+}$, but not by cAMP-dependent pathways.

\section{Introduction}

In this study the membrane permeability for $\mathrm{Cl}^{-}$of normal $(\mathrm{N})$ and cystic fibrosis (CF) keratinocytes in culture was evaluated by Ussing chamber-, patchclamp- and isotopic efflux-measurements. At present little is known about the electrophysiological response of cultured keratinocytes to neuro-hormonal agonists. Recent immunological studies suggested that the CFencoded protein, CFTR [1], is expressed at moderate levels in cultured keratinocytes [2]. Therefore, as the keratinocytes are readily available, these cells in culture were considered as an interesting new model to study the possible expression of the chloride permeability defect that characterizes $\mathrm{CF}$ epithelial cells from

Abbreviations: N, normal; $\mathrm{CF}$, cystic fibrosis; PK, protein kinase.

Correspondence: M. Kansen, Department of Cell Biology and Genetics, Medical Faculty, P.O. Box 1738, 3000 DR Rotterdam, Netherlands. distal airways [3], sweat duct [4-6], small intestine [7,8] and pancreas [9].

Electrogenic $\mathrm{Cl}^{-}$-secretion in the keratinocyte appeared to be activated in response to $\mathrm{Ca}^{2+}$-ionophore A23187, but not to $\beta$-adrenergic stimuli or the cAMP agonist forskolin. Surprisingly, in excised patches, but not in cell-attached patches of $\mathrm{N}$ and $\mathrm{CF}$ keratinocytes, an outwardly rectifying $\mathrm{Cl}^{-}$-channel with $32 \mathrm{pS}$ conductance was identified. A channel with similar biophysical properties has been shown following the exposure of airway cells to $\beta$-adrenergic stimuli in cell-attached patches $[10,11]$. In excised membrane patches of a variety of (non)-epithelial cells this channel was reported to be activated by purified catalytic subunit of protein kinase A (PK-A) or PK-C and ATP at physiological membrane potential [11-15]. In contrast, the outward rectifyer in the keratinocyte membrane could neither be activated by cAMP in intact cells nor by $\mathrm{PK}-\mathrm{A}$ or PK-C in excised patches. We identified a linear $17 \mathrm{pS} \mathrm{Cl}^{-}$-channel which, as suggested by isotopic efflux- and Ussing chamber-measurements, may be at least in part responsible for $\mathrm{Ca}^{2+}$-mediated $\mathrm{Cl}^{-}$current. 


\section{Materials and Methods}

Cell culture. Skin preparations, stripped of connestive tissue, were chopped and incubated under sterile conditions in Dulbecco's modified Eagle's medium (DMEM) with the following additions; fetal calf serum $(5 \%)$, penicillin $\left(10^{-5} \mathrm{IU}\right)$, streptomycin $(0.1 \mathrm{~g} / 1)$, epidermal growth factor $(12.5 \mu \mathrm{g} / \mathrm{l})$ and hydrocortisone $(0.5 \mathrm{mg} / \mathrm{ml})$. The skin pieces were maintained in 25 $\mathrm{cm}^{2}$ plastic (Falcon, Heidelberg). After $24 \mathrm{~h}$, the proliferating keratinocytes were co-cultured with irradiated fibroblasts feeder cells [16] to suppress fibroblast outgrowth. Before passaging the keratinocytes the feeder cells were eliminated with trypsin $(2.5 \mathrm{~g} / \mathrm{l})$ in phosphate-buffered saline. The keratinocytes were harvested in phosphate buffer containing $1 \mathrm{mmol} / \mathrm{I}$ EDTA and $2.5 \mathrm{~g} / 1$ trypsin. After washing, the cells were either grown on $0.4 \mu \mathrm{m}$ mesh Costar (Cambridge) filters for Ussing chamber measurements or on petri-dishes (Falcon) for patch-clamp analysis. The filters were confluent within 10-12 days, indicated by steady state transepithelial potential and resistance. The cells could be distinguished from sweat gland coil or duct cells, nasal polyp cells and fibroblasts on the basis of keratin content and pattern $[17,18]$. The keratinocytes could be maintained in culture for several passages. We used cells of primary outgrowth, or cells up to passage number $4,24 \mathrm{~h}$ or later after seeding.

Patch-clamp experiments. Heat polished pipettes (Corning, GC150TF-15) with 4-10 Mohm input resistance (List EPC-7) were used to monitor single channel current (filter frequency $500 \mathrm{~Hz}$ ) in inside-out patches of cells in the centre of confluent cell layers. Successfull seals (2-10 Gohm) were obtained with approx. $80 \%$ of the pipettes. The patch-pipettes were filled with $\mathrm{KCl}$ solution (Table I) and amiloride $\left(5 \cdot 10^{-5} \mathrm{M}\right.$ ). Low $\mathrm{Ca}^{2+}$ solutions were prepared by replacing $\mathrm{NaCl}$ for $\mathrm{KCl}$ in the $\mathrm{NaCl}$ solution (Table $\mathrm{I}$ ) and by adding 5 mM EGTA according to a method described by van Heeschwijk et al. [19]. Experiments were performed at room temperature. Clamp potential $\left(V_{\mathrm{c}}\right)$ is given with respect to the potential of the pipette (exterior) solution. Positive (upward) currents denote $\mathrm{Cl}^{-}$ions flowing out of the pipette into the bath. To study the effect

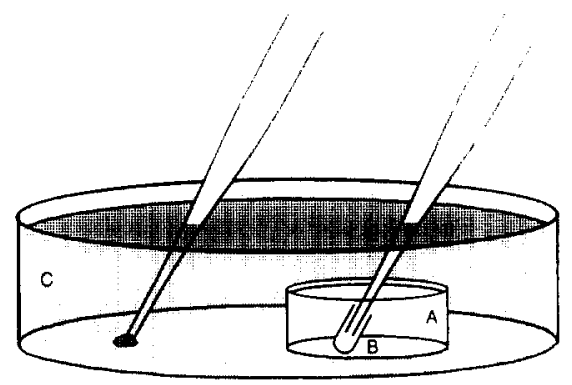

Fig. 1. Solution exchange compartment $(\Lambda)$ positioned in Petri dish (C) in which cells are grown. This compartment consists of a glass ring sealed off at the bottom with a glas cover slip. In the exchange compartment a glass capillary ( $B$, inside diameter $0.3 \mathrm{~mm}$ ) kept open at one end is glued to the bottom. After patch excision the pipette tip is positioned in the glass capillary. The fluid in the compartment is replaced by syringe suction and filling. The estimated dead volume in the device is $<4 \%$ due to dead space within the capillary and droplets sticking to the tip of the electrode salt bridge which is lodged in the compartment during the experiments. In our set-up exposing the patch to a fresh solution by raising the pipette is accomplished within 2 s.

of protein kinases and trypsin on channel activity we developed the following protocol; patches were excised at physiological membrane potential $\left(V_{i}=-40 \mathrm{mV}\right)$ and transferred within 2 min to a solution exchange compartment (Fig. 1). After solution replacement, patch activity at physiological holding potential $\left(V_{\mathrm{c}}=\right.$ $-40 \mathrm{mV}$ ) was studied for $10 \mathrm{~min}$. Hereafter, the membrane was depolarized to $V_{\mathrm{c}}=70 \mathrm{mV}$ and patch activity was studied during a second $10 \mathrm{~min}$ interval. By use of this protocol we obtained information about (i) spontaneous activation of channels in the excised patch at physiological membrane potential (i.e., approx. - 40 $\mathrm{mV}$ ); (ii) activation of channels by protein kinases and ATP at $V_{c}=-40 \mathrm{mV}$; and (iii) voltage activation of channels at $V_{c}=70 \mathrm{mV}$ that were not activated previously at physiological membrane potential.

Ussing chamber experiments. The filters and support were mounted in an Ussing chamber $\left(37^{\circ} \mathrm{C}\right)$ to monitor short circuit current $\left(I_{\mathrm{sc}}\right)$ as described previously [18].

Isotopic anion efflux studies. The method to study the isotopic effluxes of ${ }^{125} \mathrm{I}^{-}$and ${ }^{36} \mathrm{Cl}^{-}$is a slight modification of the technique used by Venglarik et al. 1990 [20] as described elswhere [21]. In short, cells,

TABLE I

Composition of Ringer's solutions ( $\mathrm{mmol} / \mathrm{l}$ )

\begin{tabular}{|c|c|c|c|c|c|c|c|c|c|c|c|}
\hline & $\mathrm{Na}^{+}$ & $\mathrm{K}^{+}$ & $\mathrm{Mg}^{2+}$ & $\mathrm{Ca}^{2+}$ & $\mathrm{Cl}^{-}$ & $\mathrm{Glu}^{-}$ & $F^{\cdots}$ & $\mathrm{Br}^{-}$ & I & $\mathrm{NO}_{3}$ & Hepes \\
\hline $\mathrm{NaCl}$ & 140 & 5 & 1 & 1.5 & 150 & - & - & - & - & - & 5 \\
\hline $\mathrm{KCl}$ & 95 & 50 & 1 & 1.5 & 150 & - & - & - & $\ldots$ & -- & 5 \\
\hline $\mathrm{NaGlu}$ & 140 & 5 & 1 & 1.5 & 10 & 140 & - & - & $n$ & - & 5 \\
\hline $\mathrm{NaF}$ & 140 & 5 & 1 & 1.5 & 10 & - & 140 & - & - & - & 5 \\
\hline $\mathrm{NaBr}$ & 140 & 5 & 1 & 1.5 & 10 & - & - & 140 & - & - & 5 \\
\hline $\mathrm{NaI}$ & 140 & 5 & 1 & 1.5 & 10 & - & - & - & 140 & - & 5 \\
\hline $\mathrm{NaNO}_{3}$ & 140 & 5 & 1 & 1.5 & 10 & - & - & -- & - & 140 & 5 \\
\hline
\end{tabular}


grown to $70-80 \%$ confluence in 6 well culture plates (34 mm $\varnothing$; Nunc), were loaded for $90 \mathrm{~min}$ with ${ }^{125} \mathrm{I}^{-}$(3 $\mu \mathrm{Ci} / \mathrm{ml})$ or ${ }^{36} \mathrm{Cl}^{-}(5 \mu \mathrm{Ci} / \mathrm{ml})$ in $1.5 \mathrm{ml}$ modified Meyler's solution at $37^{\circ} \mathrm{C}$. After washing the cells, the basal rate of isotopic efflux was measured by replacing the supernatant by fresh solution at $1-2 \mathrm{~min}$ intervals and by liquid scintillation counting. At $t=4.5 \mathrm{~min}$ the solutions were replaced by a solution containing $\mathrm{Ca}^{2+}$. ionophore or forskolin. Residual isotope was determined by adding $1 \mathrm{ml} \mathrm{NaOH}(1 \mathrm{~mol} / 1)$. Data are expressed as fractional efflux $/ \mathrm{min}$.

cAMP Determination. The accumulation of cAMP in reponse to forskolin was assessed as described previously [18].

Chemicals. The chemicals used were applied in the following concentrations ( $\mathrm{mol} / \mathrm{l})$; amiloride $\left(5 \cdot 10^{-5}\right)$, $\mathrm{Ca}^{2+}$-ionophore A23187 $\left(3 \cdot 10^{-6}\right)$, forskolin $\left(10^{-5}\right)$, indomethacin $\left(10^{-5}\right)$, 4-acetamido-4'-isothiocyanostilbene-2,4- $\beta$-phorbol-12- $\beta$-myristate- $13-\alpha$-acetate (PMA), 51B ( $3^{\prime}, 5^{\prime}$-dichlor-diphenylamino-2-carboxylic acid) $\left(10^{-4}\right), 5$-nitro-2-(3-phenylpropylamino)-benzoate (NPPB, $\left.10^{-6} \mathrm{M}, 10^{-5} \mathrm{M}, 10^{-4} \mathrm{M}\right)(51 \mathrm{~B}$ and NPPB were kindly provided by Professor R. Greger, Freiburg), 4,4'-diisothiocyanostilbene-2,2'-disulfonic acid (DIDS, $10^{-6} \mathrm{M}, 10^{-5} \mathrm{M}, 10^{-4} \mathrm{M}$ ). Homogenous preparations of purified rat lung PK-A (kindly provided by Dr U. Walter, University Clinic, Würzburg) and PK-C (kindly provided by Dr. P. Parker, U.C.R.F., London) were applied in concentrations of 200 and $160 \mathrm{nmol} / \mathrm{l}$, respectively.
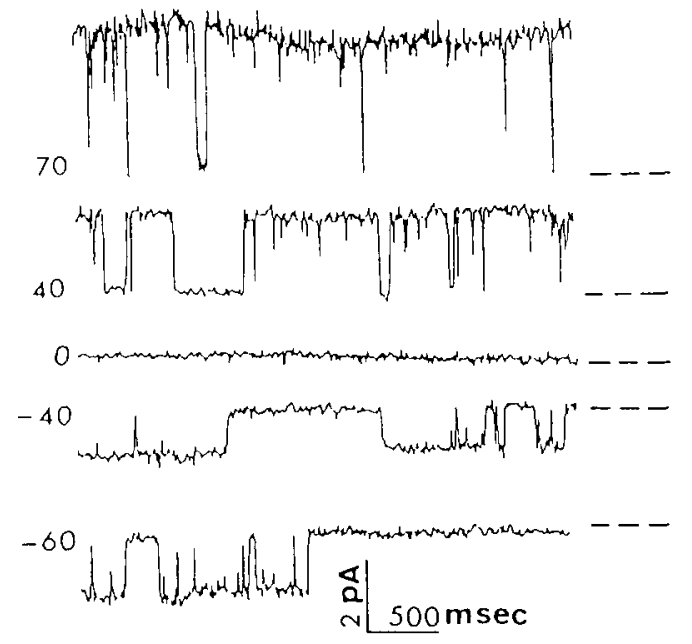

Statistics. Results are presented as mean \pm S.E. Statistical significance was evaluated using paired- or unpaired Student's $t$-tests with $P<0.05$ considered as significant.

\section{Results}

Properties of the $32 \mathrm{pS} \mathrm{Cl}^{-}$-channel in excised patches of the keratinocyte membrane. In excised patches a $31.7 \pm 1.2 \mathrm{pS}(n=20)$ channel rectifying for outward current (Fig. 2) was observed in 63\% (512 in 809) succesful seals of $\mathrm{N}$ and $67 \%$ (315 in 467) of CF cells. The channel activated after prolonged depolarization at $V_{\mathrm{c}}=70 \mathrm{mV}$ (see above). The relative anion permeability $\left(p_{\mathrm{x}} / p_{\mathrm{Cl}^{-}}\right.$; Ref 22$)$ of the channel was $1.6 \mathrm{NO}_{3}^{-} \geq$ $1.6 \mathrm{I}^{-}>1.3 \mathrm{Br}^{-}>1.0 \mathrm{Cl}^{-}>0.6 \mathrm{~F}^{-}(\mathrm{N} ; n=5)$. The 32 $\mathrm{pS} \mathrm{Cl}^{-}$-channel appeared to be impermeable for large anions like gluconate (not shown) or for cations like $\mathrm{K}^{+}, \mathrm{Na}^{+}$or $\mathrm{Cs}^{+}$. With a cation gradient across the patch in the presence of symmetrical $150 \mathrm{mmol} / \mathrm{l} \mathrm{Cl}^{-}$ ions, the current reversal potential and the channel conductance were unaffected (result not shown).

The open probability was in about $50 \%$ voltage dependent, ranging from about 0.2 at $-70 \mathrm{mV}$ to about 0.8 at $70 \mathrm{mV}$, but voltage independent in the other half of the channels (about 0.8 from $-70 \mathrm{mV}$ to $70 \mathrm{mV}$ ).

The effects of the chloride channel blockers NPPB and DIDS were assessed by addition to the cytosolic face of the excised membrane. The $32 \mathrm{pS}$ Cl-channel

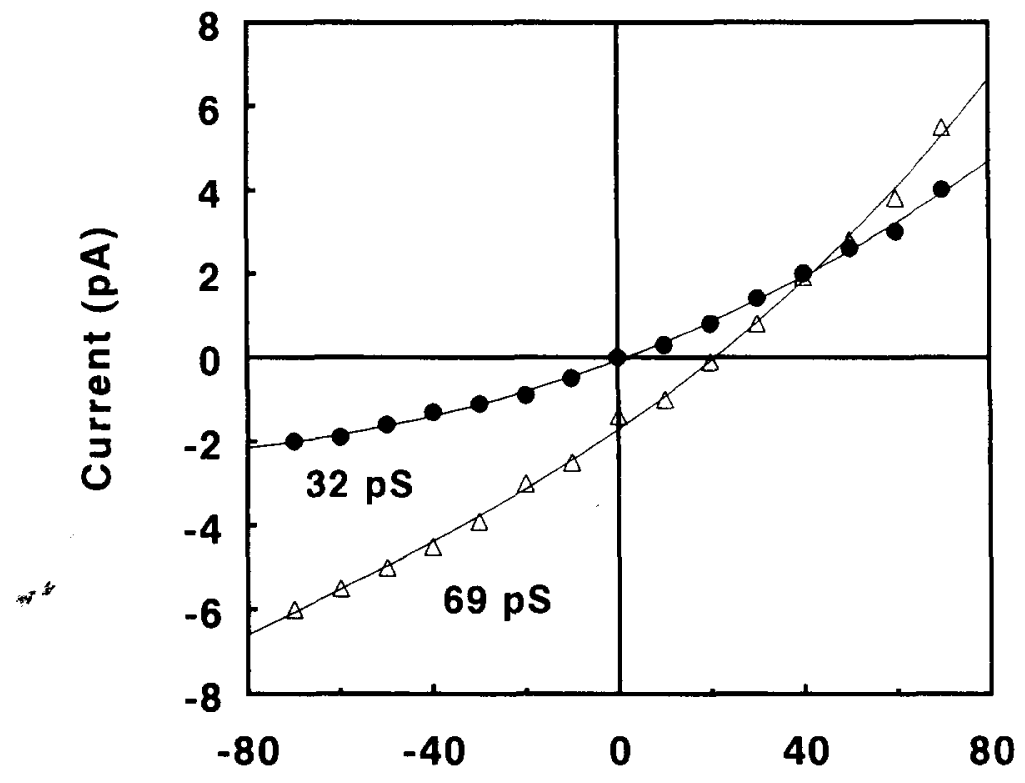

Holding Potential (mV)

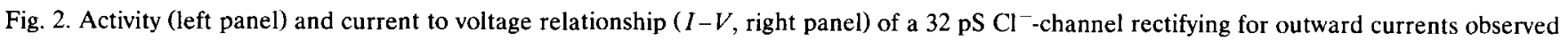
in excised patches of $\mathrm{N}$ and $\mathrm{CF}$ keratinocytes. Dashed line: closed state of the channel. 


\section{TABLE II}

Keratinocye chloride channel actiration in excised patches hy ambicm internal $\mathrm{Ca}^{2+}-$ concentration or trypsin at $V_{c}=-40 \mathrm{mV}$, or ioltage at $\mathrm{l}_{\mathrm{r}}=70 \mathrm{m \textrm {V }}$

$\mathrm{Ca}^{2}$ or trypsin activation of the channel was studied for 10 min at $-40 \mathrm{mV}$, whereafter the patch was depolarized to $70 \mathrm{mV}$ holding potential.

\begin{tabular}{llrrr}
\hline Bath & $\begin{array}{l}\text { Bath calcium } \\
(\mathrm{mol} / \mathrm{l})\end{array}$ & $n^{\text {a }}$ & $-40 \mathrm{mV}$ & $70 \mathrm{mV}$ \\
\hline Sham & $10^{-3}$ & 15 & 5 & 10 \\
& $10^{-5}$ & 9 & 3 & 6 \\
& $10^{-7}$ & 12 & 3 & 9 \\
& $10^{-8}$ & 32 & 0 & 32 \\
Trypsin & $10^{-8}$ & 9 & 9 & 0 \\
$0.05 \%$ & & & & \\
\hline
\end{tabular}

a Number of patches containing channel activity.

was reversibly inhibited by both blockers. NPPB and DIDS affected the open probability of the channel by inducing flickering. The NPPB and DIDS concentration with half maximal effect on the channel open probability were $9 \cdot 10^{-6} \mathrm{~mol} / \mathrm{l}$ and $5 \cdot 10^{-6} \mathrm{~mol} / \mathrm{l}$, respectively (M. Kansen et al., unpublished data).

Spontaneous activation of the channel at physiological holding potential $\left(V_{c}=-40 \mathrm{mV}\right)$. In $\operatorname{dog}$ and $\mathrm{N}$ and $\mathrm{CF}$ human tracheal epithelial cells the outwardly rectifying $\mathrm{Cl}^{-}$-channel (i) remained closed in excised membrane patches clamped at physiological holding potential $[14,15]$ and (ii) is activated by applying large depolarizing potentials $\left(V_{c}>50 \mathrm{mV}\right)$. This finding offered a suitable experimental condition to study the activation of the channel by regulatory enzymes, like PK-A and PK-C, added to the solution of the excised patch. In setting up conditions to study phosphorylation-induced activation of the keratinocyte outwardly rectifying $\mathrm{Cl}^{-}$-
TABLE $11 \mathrm{I}$

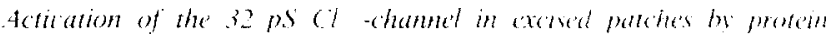
kinases and coltage depolarization

$n=$ number of patches with channel activity. The Cat concentrat tion in the bath was $10^{*} \mathrm{~mol} / \mathrm{I}(\mathrm{sec}$ Table $V)$

\begin{tabular}{ll}
$\begin{array}{l}\text { Number of } \\
\text { patches }\end{array}$ & $-40 \mathrm{mV} \quad 70 \mathrm{mV}$ \\
\hline
\end{tabular}

\begin{tabular}{|c|c|c|c|}
\hline \multicolumn{4}{|l|}{ Activation: } \\
\hline $\mathrm{PK}-\mathrm{A}+\mathrm{ATP}$ & 15 & 0 & 15 \\
\hline $\mathrm{PK}-\mathrm{C}^{\mathrm{a}}+\mathrm{ATP}+\mathrm{PMA}$ & 11 & 0 & 11 \\
\hline
\end{tabular}

channel at $V_{\mathrm{c}}=-40 \mathrm{mV}$, we found that within a time span of 10 min upon excision about $30 \%$ of the $\mathrm{Cl}^{-1}$ channels became spontaneously activated if the internal $\mathrm{Ca}^{2+}$ was raised above $10^{-7} \mathrm{~mol} / \mathrm{l}$ (Table II). With $10^{-8} \mathrm{~mol} / \mathrm{I} \mathrm{Ca}^{2+}$ in the internal solution, spontaneous activation of the channel was prevented (Table II). These results suggested that the $32 \mathrm{pS}$ channel activation in keratinocyte membranes is susceptible to alterations in internal $\mathrm{Ca}^{2+}$, although the molecular mechanism involved is as yet unclear.

Activation of the outwardly rectifying channel by protein kinase $A(P K-A)$, protein kinase $C(P K-C)$ and trypsin. The assays (i) to activate the channel at physiological holding potential with PK-A or PK-C in the presence of $10^{-8} \mathrm{mmol} / \mathrm{I} \mathrm{Ca}^{2+}$ and $1 \mathrm{~mol} / 1 \mathrm{ATP}$ and PMA (ii) to inactivate the channel by PK-C in the presence of $10^{-6} \mathrm{mmol} / 1 \mathrm{Ca}^{2+}$ and $1 \mathrm{~mol} / \mathrm{l} \mathrm{ATP}$, as described previously $[14,15]$, were not successful when applied to the channel of the keratinocyte (Table III). However, activation of the $32 \mathrm{pS}$ channel was successful within $1 \mathrm{~min}$ after exposing the internal site of the
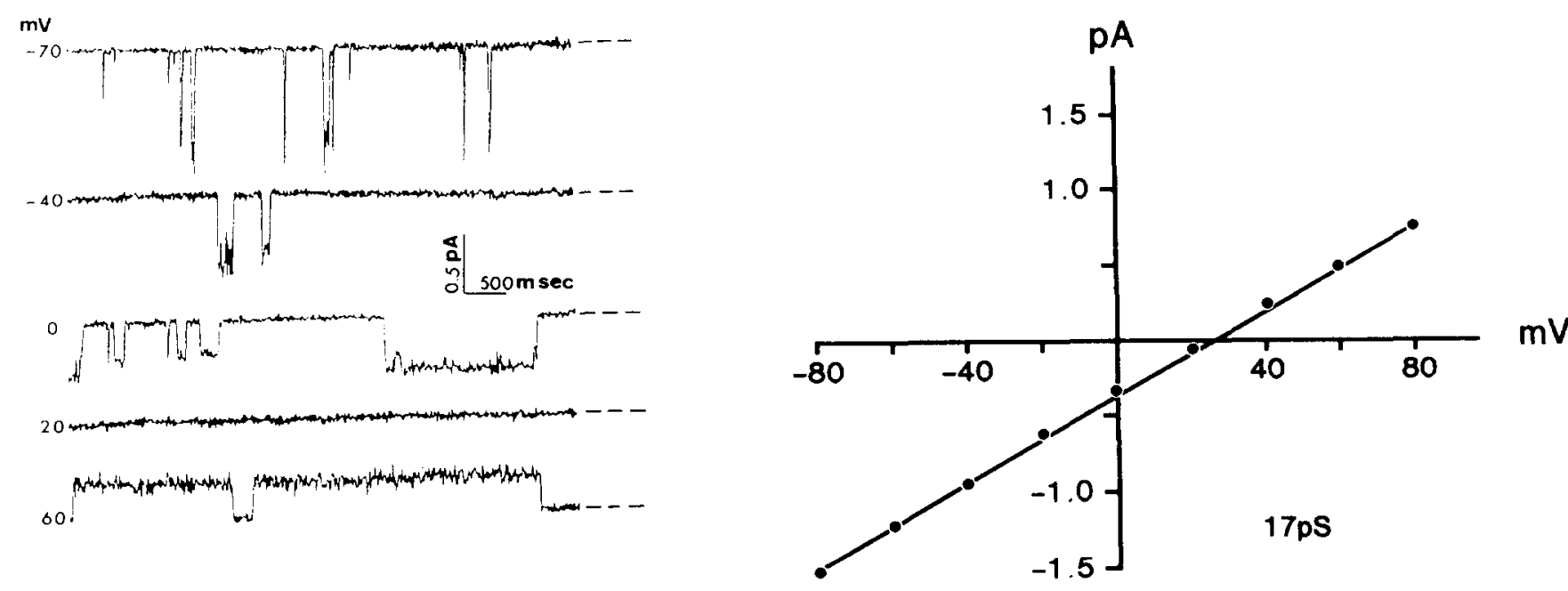

Fig. 3. Activity (left panel) and current to voltage relationship ( $I-V$, right panel) of a $17 \mathrm{pS}$ channel observed in $\mathrm{N}$ and $\mathrm{CF}$ cell-attached patches of keratinocytes exposed to A23187 (see Table IV). Channel activity disappeared upon excision of the patch. Dashed line: closed state of the channel. 


\section{TABLE IV}

Number of cell-attached-and excised patches of $N$ cells pre-treated with different agonists that contained 17 and / or 32 pS channel activity

Cell attached activity was monitored at $-40 \mathrm{mV}$ holding potential; thereafter channel activity was monitored for $10 \mathrm{~min}$ at $70 \mathrm{mV}$ (see text).

\begin{tabular}{|c|c|c|c|}
\hline & Control & Forskolin & A23187 \\
\hline \multicolumn{4}{|l|}{ Cell-attached activity: } \\
\hline $17 \mathrm{pS}$ channel $^{\mathrm{a}}$ & 5 & 2 & 9 \\
\hline $32 \mathrm{pS}$ channel & 0 & 0 & 0 \\
\hline \multicolumn{4}{|l|}{ Excised activivity: } \\
\hline 17 pS channel & 0 & 0 & 0 \\
\hline $32 \mathrm{pS}$ channel ${ }^{\mathrm{b}}$ & $34^{c}$ & $11^{\mathrm{d}}$ & $14^{\mathrm{c}}$ \\
\hline Total No. of patches examined & 57 & 17 & 20 \\
\hline
\end{tabular}

a See Fig. 3.

${ }^{\text {b }}$ See Fig. 5.

c One of these patches contained previously cell-attached activity of the $17 \mathrm{pS}$ channel.

${ }^{d}$ None of these patches contained previously cell-attached activity of the $17 \mathrm{pS}$ channel.

- Five of these patches contained previously cell-attached the $17 \mathrm{pS}$ channel.

membrane to trypsin $(0.05 \%$; Table II). A similar activation of the outward rectifyer by trypsin has been reported earlier in excised patches from $\mathrm{N}$ and $\mathrm{CF}$ human airway cells [11], the channel was activated within 1 min after addition of trypsin.

Channel activity in cell-attached patches, effects of agonists. In $7 \%$ of the $\mathrm{N}(5$ in 57 seals) and $6 \%$ of CF cell-attached patches ( 5 in 85 seals) of resting cells a $17.1 \pm 3.6 \mathrm{pS}(n=5)$ channel was identified with linear $I-V$ characteristic (Fig. 3). When present, the activity of this channel was apparent immediately after seal formation. At depolarized membrane potential the channel remained closed for long periods. The channel activity disappeared upon excision of the membrane patch. The reversal potential of cell-attached channel current was $15.0 \pm 3.6 \mathrm{mV}(n=5)$. Since changing of the $\mathrm{K}^{+}$-concentration in the patch-pipette did not result in the appearance of other channels, indicating that the channel is $\mathrm{Cl}^{-}$-selective. From the reversal potential it was calculated that in the cell $\mathrm{Cl}^{-}$-ions are accumulated approx. 1.8-fold above electrochemical equilibrium (as calculated according to Ref. 23).

In a second series of experiments we examined cell-attached activity (Table IV) in a 10 minute episode after preincubating the cells with foskolin or $\mathrm{Ca}^{2+}$. ionophore. Addition of forskolin had no affect on cell-attached single channel activity and the channel incidence was about the same as in resting cells (approx. 12 and $7 \%$, respectively). However, we observed that in cell-attached patches of $\mathrm{N}$ cells pretreated with $\mathrm{Ca}^{2+}$-ionophore the incidence of the $17 \mathrm{pS}$ channel activity increased from approx. 8 to $45 \%$ ( 9 in 20 patches). After excision the channel activity disappeared and the membrane patch was further analyzed for channel activity during a second period of $10 \mathrm{~min}$ at depolarized membrane potential $\left(V_{\mathrm{c}}=70 \mathrm{mV}\right)$. In $63 \%$ of these excised patches a $32 \mathrm{pS}$ outwardly rectifying Cl-channel was apparent $0-8$ min after depolarization independent of pre-stimulation with either forskolin (11 channels in 17 patches) or A23187 (14 channels in 20 patches; Table IV). The activity of the $32 \mathrm{pS}$ outwardly rectifying $\mathrm{Cl}^{-}$channel appeared $2.1 \pm 0.2 \mathrm{~min}$ (control; $n=7$ ), $2.3 \pm 0.4 \mathrm{~min}$ (forskolin; $n=7$ ) and $2.7 \pm 0.6 \min (\mathrm{A} 23187 ; n=6)$ after the onset of depolarization for $\mathrm{N}$ and $\mathrm{CF}$ cells.

Ussing chamber-measurements and isotopic efflux studies. The $I_{\mathrm{sc}}$ responses of filter-grown monolayers of keratinocytes are summarized in Table V. A representative recording of the $I_{\mathrm{sc}}$ and the effect of agonists is

TABLE V

$I_{s c}\left(\mu \mathrm{A} / \mathrm{cm}^{2}\right)$ and change in $I_{s c}\left(\Delta I_{s c}\right)$ in response to agonists of $N$ and $C F$ keratinocytes mounted in the Ussing chamber and exposed to NaCl or Na gluconate ( $\mathrm{NaGlu}$ ) Ringer's solution

The cells were obtained from $7 \mathrm{~N}$ individuals and $7 \mathrm{CF}$ patients. Number of observations in parentheses ${ }^{a}$.

\begin{tabular}{|c|c|c|c|c|}
\hline & \multicolumn{2}{|l|}{$\mathrm{NaCl}$} & \multicolumn{2}{|l|}{$\mathrm{NaGlu}$} \\
\hline & $\begin{array}{l}\bar{N} \\
(21)\end{array}$ & $\begin{array}{l}\mathrm{CF} \\
(23)\end{array}$ & $\begin{array}{l}\bar{N} \\
(8)\end{array}$ & $\begin{array}{l}\mathrm{CF} \\
\text { (5) }\end{array}$ \\
\hline$I_{\mathrm{sc}}$ (resting) & $+1.23 \pm 0.37$ & $+0.90 \pm 0.23$ & $+1.44 \pm 0.49$ & $+1.25+0.33$ \\
\hline 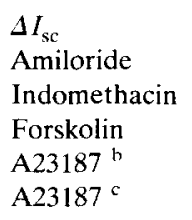 & $\begin{array}{l}-0.51 \pm 0.19 \\
-0.15 \pm 0.09 \\
\quad 0.0 \\
+1.22 \pm 0.15 \\
+1.32 \pm 0.17\end{array}$ & $\begin{array}{l}-0.51 \pm 0.11 \\
-0.15 \pm 0.06 \\
\quad 0.0 \\
+0.70 \pm 0.23 \\
+0.85 \pm 0.19\end{array}$ & $\begin{array}{l}-0.24 \pm 0.26 \\
-0.16 \pm 0.09 \\
\quad 0.0 \\
+1.35 \pm 0.21 \\
\quad 0.0\end{array}$ & $\begin{aligned}- & 0.77+0.24 \\
- & 0.13+0.17 \\
& 0.0 \\
+ & 1.22 \pm 0.26 \\
& 0.0\end{aligned}$ \\
\hline
\end{tabular}

\footnotetext{
a The responses of amiloride and the A23187 (except the sustained A23187 response in NaGlu) were significantly different from the resting values.

b Peak response.

c Sustained response (see Fig. 5).
} 

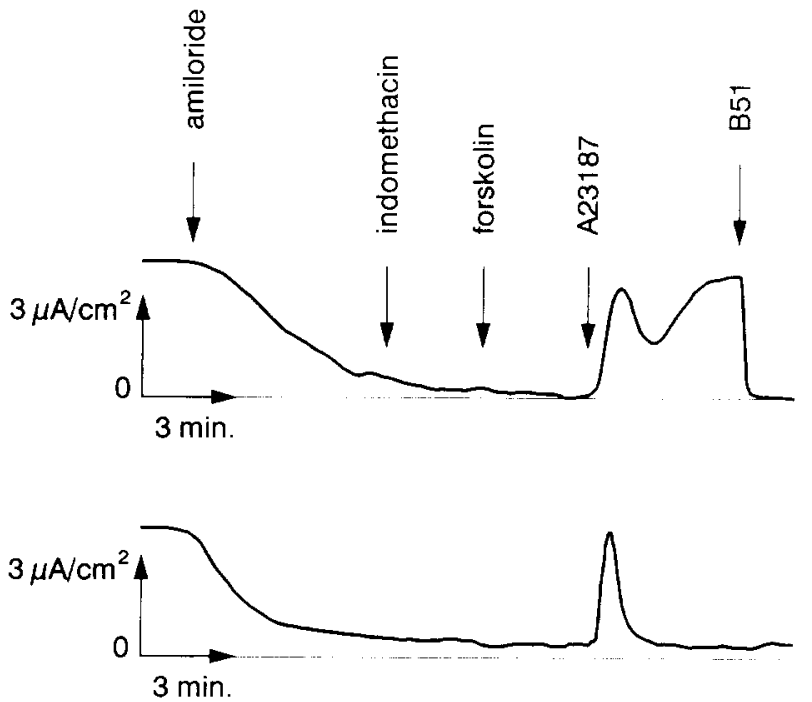

Fig. 4. Redraw of original recordings of Isc across $\mathrm{N}$ skin cells mounted in the Ussing chamber in chloride- (upper tracing) or gluconate-containing solution (lower tracing). Similar responses were obtained for CF cells (not shown). Concentrations (mol/l): Amiloride $\left(5 \cdot 10^{-5}\right)$, indomethacin $\left(10^{-5}\right)$, A23187 $\left(3 \cdot 10^{-6}\right)$, forskolin $\left(10^{-5}\right)$, B51 $\left(10^{-4}\right)$.

given in Fig. 4. The effects of secretagogues on $I_{\mathrm{sc}}$ were studied in the presence of amiloride and indomethacin. Mucosal amiloride reduced basal $I_{\mathrm{sc}}$ by $40-$ $50 \%$ in $\mathrm{N}$ and $\mathrm{CF}$ cells, indicating the presence of an amiloride sensitive $\mathrm{Na}^{+}$-conductance in the apical membrane of the cells (Table V). The effect of indomethacin, an inhibitor of endogenous prostaglandin synthesis on $I_{\mathrm{hc}}$ was not significantly different between $\mathrm{N}$ and CF cells. The effect of secretagogues that raise intracellular $\mathrm{Ca}^{2+}$ or cAMP levels was studied by adding $\mathrm{Ca}^{2+}$-ionophore $\mathrm{A} 23187$ and the adenylate cyclase activator forskolin, respectively. Forskolin did not affect basal $I_{\mathrm{sc}}$ (Table $V$ ) although intracellular cAMP concentration showed a 50 -fold increase, from $0.45 \pm$ $0.25 \mathrm{pmol} \mathrm{cAMP} / \mathrm{mg}$ protein $(n=2)$ to $28.3 \pm 3.5 \mathrm{pmol}$ $\mathrm{cAMP} / \mathrm{mg}$ protein after simulation with forskolin. The addition of $\mathrm{Ca}^{2+}$-ionophore resulted in a sustained increase in $l_{\mathrm{sc}}$ which was not significantly different between $\mathrm{N}$ and $\mathrm{CF}$ cells (Table V: Fig. 5). The sustained A23187-provoked $I_{\mathrm{sc}}$ response was abolished by the $\mathrm{Cl}^{-}$-channel blocker 51B (Fig. 5), and was inhibited in part following replacement of $\mathrm{Cl}$ in the bathing fluids by gluconate (Fig. 5, Table $\mathrm{V}$ : sustained response). The rapid and transient response observed in the gluconate solution is most probably due to the opening of $\mathrm{K}^{+}$-channels.

The $\mathrm{Ca}^{2+}$-induced $\mathrm{Cl}^{-}$-permeability of the cell membrane was further assessed by measuring the ${ }^{125} \mathrm{I}$ and ${ }^{36} \mathrm{Cl}^{-}$-efflux rates in isotope-loaded $\mathrm{N}$ and $\mathrm{CF}$ keratinocytes (Fig. 5). Addition of A23187 resulted in an acceleration of ${ }^{125} \mathrm{I}^{-}$- or ${ }^{36} \mathrm{Cl}^{-}$-efflux in both $\mathrm{N}$ and $\mathrm{CF}$ cells. In contrast, the efflux of ${ }^{125} \mathrm{I}^{-}$or ${ }^{36} \mathrm{Cl}^{-}$was not affected by forskolin in $\mathrm{N}$ and $\mathrm{CF}$ cells. The estimated efflux ratio $\mathrm{Cl}^{-} / \mathrm{I}^{-}$was 0.7 in $\mathrm{N}$ and $\mathrm{CF}$ cells stimulated with $\mathrm{A} 23187$. These values agree well with resting and $\mathrm{Ca}^{2+}$-provoked $\mathrm{Cl}^{-} / \mathrm{I}^{-}$efflux and anion channel selectivity ratio's of HT-29cl.19a- and $\mathrm{T}_{84}$ colonocytes $[20,21,24]$.
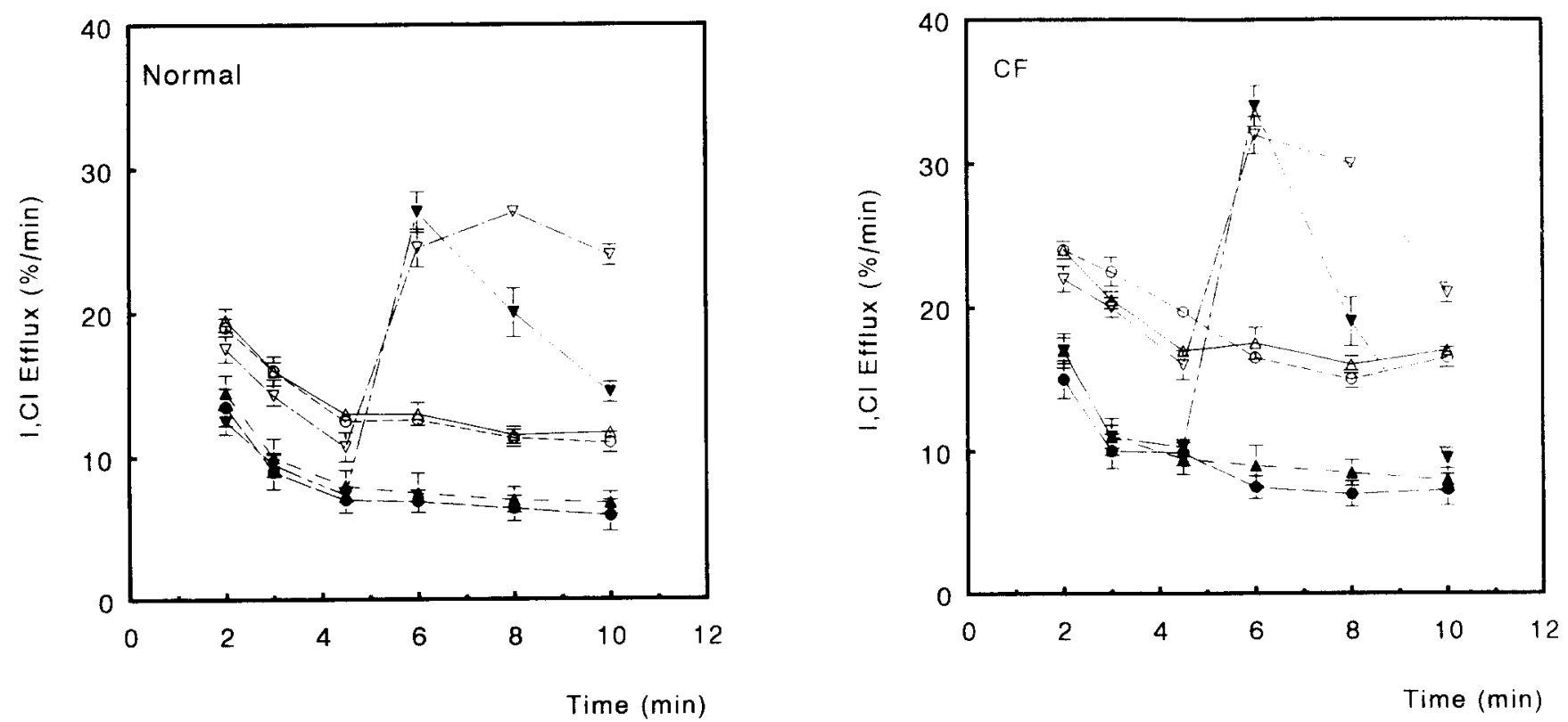

Fig. 5. ${ }^{125} \mathrm{I}^{-}$(closed symbols) and ${ }^{36} \mathrm{Cl}^{-}$- (open symbols) efflux of $\mathrm{N}$ (left panel) and CF (right panel) keratinocytes in response to forskolin or A23187. Agonists and vehicle ( $0.1 \%$ ethanol) or vehicle alone (control) were added at $t=4.5 \mathrm{~min}$. The $\mathrm{N}(n=3)$ and $\mathrm{CF}(n=3)$ cells responded similarly to A23187. A forskolin response was absent in $\mathrm{N}$ and $\mathrm{CF}$ cells. $-{ }^{36} \mathrm{Cl}^{-}$control, $\bigcirc-\mathrm{O}^{36} \mathrm{Cl}^{-}$forskolin, $\nabla-\nabla{ }^{36} \mathrm{Cl}$ $\mathrm{A} 23187, \Delta \longrightarrow \Delta^{125} \mathrm{I}^{-}$control, $\Delta \longrightarrow{ }^{125} \mathrm{I}^{-}$forskolin, $\square \longrightarrow{ }^{125} \mathrm{I}^{-} \mathrm{A} 23187$. 
Our observations suggest that at least part of the $\mathrm{Ca}^{2+}$-mediated $I_{\mathrm{sc}}$-increase in the Ussing chamber experiments can be ascribed to activation of a $\mathrm{Cl}^{-}$-permeability. Also, the absence of a forskolin induced ${ }^{125} \mathrm{I}^{-}$or ${ }^{36} \mathrm{Cl}^{-}$-efflux strongly suggest that cAMP-triggered electrogenic $\mathrm{Cl}^{-}$-secretion is absent in the keratinocyte.

\section{Discussion}

In this study we have evaluated the agonist dependency of $\mathrm{Cl}^{-}$-secretion in $\mathrm{N}$ and $\mathrm{CF}$ cultured human keratinocytes by three different methods, i.e., Ussing chamber-, patch clamp- and isotope efflux-measurements. The results of the three methods are in agreement and suggest that in both $\mathrm{N}$ and $\mathrm{CF}$ cells $\mathrm{Cl}^{-}$secretion is stimulated by elevation of intracellular $\mathrm{Ca}^{2+}$ (Figs. 4 and 5; Table IV and V), whereas in both cell types $\mathrm{Cl}^{-}$-secretion in response to elevation of intracellular cAMP levels by forskolin is absent (Figs. 4 and 5). The presence of $\beta$-adrenergic control of $\mathrm{Cl}^{-}$secretion is common to most exocrine epithelial cells, while lack of $\beta$-adrenergic controlled $\mathrm{Cl}^{-}$-secretion is a common characteristic of $\mathrm{CE}$ exocrine epithelial cells.

It has been reported that a $30-40 \mathrm{pS}$ outwardly rectifying chloride channel in $\mathrm{N}$ but not in $\mathrm{CF}$ epithelial cells could be activated in excised patches by PKA $[4,12,14]$. Therefore, we thought to bypass macroscopic $\mathrm{Cl}^{-}$current measurements and start directly to activate this channel in $\mathrm{N}$ and $\mathrm{CF}$ keratinocytes by phosphorylation. Since this activation in $\mathrm{N}$ keratinocytes was unsucessful, we were obliged to investigate the stimulation of $\mathrm{Cl}^{-}$transport at the level of Ussing chamber- and isotopic-anion efflux-measurements.

The $I_{\mathrm{sc}}$ response of $\mathrm{CF}$ cells was similar to that of normal cells. In both cell types the overall $I_{\mathrm{sc}}$ response $\left(<2 \mu \mathrm{A} / \mathrm{cm}^{2}\right)$ was rather low as compared to other epithelial cells [25]. This may originate from culturing conditions, a cell cycle dependency of $\mathrm{Cl}^{-}$channel expression [26] or, in analogy to HT29.cl19A colon carcinoma cells $[20,21]$, from a symmetrical distribution of $\mathrm{Cl}^{-}$conductive pathways among the apical and basolateral keratinocyte membrane. The reversal potential of the $17 \mathrm{pS}$ channel ( $15 \mathrm{mV}$; Fig. 3) is expected for a channel that is $\mathrm{Cl}^{-}$-selective and suggests that in the keratinocyte $\mathrm{Cl}^{-}$-ions are accumulated above electrochemical equilibrium like in other $\mathrm{Cl}^{-}$-secreting epithelial cells [27]. The increase in the incidence upon $\mathrm{Ca}^{2+}$ ionophore treatment (Table IV) suggests, that this $17 \mathrm{pS}$ channel might carry at least part of the $\mathrm{Ca}^{2+}$-ionophore provoked $I_{\text {sc }}$ and ${ }^{36} \mathrm{Cl}^{-}$or ${ }^{125} \mathrm{I}^{-}$efflux observed in cultured $\mathrm{N}$ and $\mathrm{CF}$ keratinocytes. However, we cannot rule out that part of the isotopic efflux is carried by $\mathrm{Cl}^{-}$-exchangers. Interestingly, $\mathrm{Ca}^{2+}$-ionophore provoked $\mathrm{Cl}^{-}$-secretion is likewise unmodified in
CF sweat gland coil cells and pancreas carcinoma cells [28,29], CF nasal polyp and tracheal cells [18,30,32], but apparently defective in $\mathrm{CF}$ intestine and synchronized lymphocytes $[23,24,26]$.

The $17 \mathrm{pS} \mathrm{Cl}^{-}$channel was observed only in cell-attached patches, the $32 \mathrm{pS} \mathrm{Cl}^{-}$-channel only in excised patches. They are, however, not related. The number of $32 \mathrm{pS} \mathrm{Cl}-$-channels in excised patches was similar in previously cell-attached patches of cells stimulated with $\mathrm{Ca}^{2+}$-ionophore that contained $17 \mathrm{pS}$ channel activity (65\%, Table IV) as compared to non prestimulated cells $(63 \%)$. The absence of cAMP-triggered $\mathrm{Cl}^{-}$-secretion in the keratinocyte is of particular interest because a similar $32 \mathrm{pS}$ rectifying $\mathrm{Cl}^{-}$-channel, identified in excised membrane patches of other epithelial cells, has been reported to have altered $\beta$-adrenergic regulatory property in CF $[10,12,14,22,15]$. In human airway epithelial cells and lymphoblasts, this $32 \mathrm{pS} \mathrm{Cl}^{-}$-channel has been reported to be activated (a) in cell-attached patches in response to $\beta$-adrenergic agonists and 8 Br-cAMP and (b) in excised membrane patches held at physiological membrane potentials by the addition of ATP plus PK-A and PK-C $[11,12,14,15]$. In spite of extensive efforts, these agents failed to induce activation of the $\mathrm{Cl}^{-}$channel under similar conditions in cultured human keratinocytes (Table III). Nevertheless the channel characteristics and sensitivity to blocking agents are indistinguishable to the outwardly rectifying $\mathrm{Cl}^{-}$channel which is expressed in many (non)-epithelial cells $[10,11,13,22,32,33,34]$. The apparent insensitivity of the keratinocyte $32 \mathrm{pS}$ channel to phosphorylating enzymes may suggest that an unidentified regulatory component associated with the membrane, conferring protein kinase sensitivity to the $\mathrm{Cl}^{-}$-channel, is missing in this cell type. Furthermore, lipid and/or steric effects may be responsible for the unsuccessful activation of this channel in excised patches. However, the importance of the outwardly rectifying channel in $\mathrm{Cl}^{-}$-secretion may be overestimated since a number of studies failed to detect a significant level of cell-attached activity of the $32 \mathrm{pS} \mathrm{Cl}-$-channel in cultured pancreatic duct cells [33], Necturus choroid plexus [32], colon carcinoma T84 cells [35], distal nephron [36] and thyroid cells [37]. In these cells cAMP/PKA activated $\mathrm{Cl}^{-}$-channel activity is non-voltage rectifying with approx. $5 \mathrm{pS}$ channel conductance while activity of the 32 $\mathrm{pS} \mathrm{Cl}^{-}$-channel in the cell-attached configuration is sporadically observed. Very recently this small $\mathrm{Cl}^{-}$channel was shown to be present after cAMP stimulation in an insect cell line infected with a viral vector expressing CFTR [38].

The physiological role of the excised $32 \mathrm{pS}$ rectifying channel is yet unclear. In a preliminary report it is suggested that the channel might be active in volume regulation [39] which may explain the finding that the channel is observed in many non-epithelial cells. 


\section{References}

1 Kerem, B.-S., Rommens, J., Buchanan, J.A.. Markiewicz, D. Cox, T., Chakravarti, A., Buchwald, M. and Tsui, L.-C. (1989) Science 245, 1073-1080.

2 Hoogeveen, A.T., Keulemans, J., Willemsen, R., Scholte, B.J., Bijman, J., Edixhoven, M.J., De Jonge, H.R. and Galjaard, H. (1991) Exp. Cell Res. 193, 435-437.

3 Knowles, M.R., Stutts, M.J., Spock, A., Fischer, N., Gatzy, J.T. and Boucher, R.C. (1983) Science 211, 1067-1070.

4 Bijman, J., Englert, H.C., Lang, H.J., Greger R. and Frömter, E. (1987) Pflügers Arch. 408, 511-514.

5 Quinton, P.M. (1984) Nature 301, 421-422.

6 Quinton, P.M. and Bijman, J. (1983) N. Engl. J. Med. 308, $1185-1189$.

7 De Jonge, H.R., Bijman, J. and Sinaasappel, M. (1987) Ped. Pulmonol. Suppl. 1, 54-57.

8 De Jonge, H.R., Bijman, J. and Sinaasappel, M. (1988) Ped. Pulmonol. Suppl. 2, 93-95.

9 Kopelman, H., Corey, M., Gaskin, K., Durie, P., Weizman, Z. and Forstner, G. (1988) Gastroenterol. 95, 349-355.

10 Frizzell, R.A., Rechkemmer, G. and Shoemaker, R.L. (1986) Science 233, 558-560.

11 Bear, C.E. (1988) FEBS Lett. 237, 145-149.

12 Chen, J.H.. Schulman, H. and Gardner, Ph. (1989) Science 24.3, 657-660).

13 De Jonge, H.R., Van den Berghe, N., Tilly, B.C., Kansen, M. and Bijman, J. (1989) Biochem. Soc. Trans. 17, 816-818.

14 Li, M., McCann, J.D., Liedtke, C.M., Nairn, A.C., Greengard, P. and Welsh, M.J. (1988) Nature 331, 358--360.

15 Schoumacher, R.A., Shoemaker, R.L., Halm, D., Tallant, E.A., Wallace, R.W. and Frizzell, R.A. (1987) Nature 330, 752-754

16 Rheinwald, R.H. and Green, H. (1975) Cell 6, 331-334.

17 Keulemans, J., Van Heyningen, V., Scholte, B.J., Bijman, J., Van der Kamp, A.W.M., Kansen, M., De Jonge, H., Galjaard, H. and Hoogeveen, A.T. (1991) Biochem. Biophys. Res. Commun. 174. $1281-1286$.

18 Verbeek, E., De Jonge, H.R., Bijman, J., Keulemans, J., Sinaasappel, M., Van der Kamp, A.W.M. and Scholte, B.J. (1990) Pflügers Arch. 415, 540-546.

19 Heeschwijk, M.P.E., Geertsen, J.A.M. and Van Os, C.H. (1984) J. Membr. Biol. 79, 19-31.
20) Venglarik. (.I., Bridges. R.J. and Frizzell, R.A. 1 (490) An. I Physiol. 259, (358-C364.

21 Vaandrager, A.B., Bajnath, R.. Groot, J.A. Bot. A.G.M. and D. Jonge, H.R. (1991). Am. J. Physiol., in press.

22 Kunzelmannn, K.. Pavenstädt. H. and Greger. R, (1989) Pflügers Arch. 415, 172-182.

23 Clancy, W.H., McCann, J.D. and Welsh, M.J. (I990) Am. J. Physiol. 258, L25-1.32.

24 Cliff, W.H. and Frizzell, R.A. (1990) Proc. Natl. Acad. Sci. USA $87,4956-4960$ )

25 Willumsen, N.J. and Boucher, R.C. (1989) Am. J. Physiol. 256, C $1054-\mathrm{C} 1063$

26 Bubien, J.K. Kirk, K.L., Rado, T.A. and Frizzell, R.A. (1990) Science 258, 1416-1419.

27 Welsh, M.J. (1986) Clin. Chest Med. 7, 273-283.

28 Frizzell, R.A., Shoumacher, R.A., Shoemaker, R.L. and Halm. D.R. (1987) Ped. Pulmonol. Suppl. 1, 24-25.

29 Schoumacher, R.A., Ram, J., Ianuzzi, M.C., Bradbury, N.A. Wallace, R.W., Tom Hon, C., Kelly, D.R., Schmid, S.M., Gelder, E.B., Rado, T.A. and Frizzell, R.A. (1990) Proc. Natl. Acad. Sci. USA 87. 4012-4016.

30) Wagner, J.A., Cozens, A.L., Schulman, H., Gruenert, D.C., Stryer. L. and Gardner, P. (1991) Nature 349, 793-796.

31 Willumsen. N.J. and Boucher. R.C. (1989) Am. J. Physiol. 256. C226-C233.

32 Christensen, O., Simon, M. and Randlev. T. (1989) Pflügers Arch. $415.37-46$

33 Gray, M.A., Harris, A., Coleman, L., Greenwell, J.R. and Argent. B.E. (1989) Am. J. Physiol. 257, C240-C251

34 Welsh. M.J. (1986) Science 232, 1648-1650.

35 Tabcharani, J.A., Low, W., Elie. D. and Hanrahan J.W. (1990) FEBS Letters 270, 157-164.

36 Marunaka. Y. and Eaton, D.C. (1990) Am. J. Physiol. 258, (352 C 368 .

37 Champigny, G., Verrier, B., Gerard, C., Mauchamp. J. and Latz. dunski, M. (1990) FEBS Lett. 259, 263-268.

38 Kartner, N., Hanrahan, J.W.. Jensen, T.J., Naismith, A.L., Sun, S., Ackerley, C.A., Reyes, E.F., Tsui, L.-C., Rommens, J.M., Bear, C.E. and Riordan, J.R. (1991) Cell 84. 681-691.

39 Solc, C.K., Law, T.C., Ward. C.L. and Wine J.J. (1990) Ped. Pulmonol. Suppl. 5, 213-214.

40 Welsh, M.J., Li, M. and McCann, J.D. (1989) J. Clin. Invest. 84. $2002-2007$. 